Psychological problems of isolation in adults and children are kept to a minimum by constant attention by the nursing staff, allowing almost unrestricted visiting, and supplying each patient with a television set. A further problem concerned the transfer of chronic salmonellae carriers to geriatric units; in one instance a carrier remained in the ward for six months. Nevertheless, the selection of patients and decisions on discharge are not usually a problem, and the infection control officers make the final decision in the event of disagreement.

An isolation unit fulfils a useful role in a general hospital despite the cost of nursing staff. The number of cubicles (12 for a hospital of 730 patients) was generally adequate, and a smaller unit would not be viable. More cubicles-say, up to 20 -might be required if children with infections were also routinely nursed in the ward. More patients, however, may create additional nursing problems, including a range of specialist knowledge and experience, and standards may fall. It should be possible to keep all patients with communicable diseases in such a unit-apart from long-term patients with, say, tuberculosis-but this also depends on the isolation requirements for immunosuppressed patients. It would rarely be justified, owing to expense and other problems of special units, to have separate wards for infected and immunosuppressed patients. The cost of the unit itself could be reduced by lessening the complexity of the ventilation system without greatly increasing the risk of infection. Providing extractor fans in four cubicles would probably be enough to reduce the risk of airborne spread from the more highly communicable diseases, but supplementary heating may be required, as heat loss may be excessive. Preventing contact spread is much more important than preventing airborne spread, and simple and safe techniques are all that are required provided that the very highly communicable or dangerous infections-for example, Lassa feverare excluded.

We thank Sister A Etheridge and the nursing staff of the ward for their co-operation, and Mrs J Davies and Miss C Bradley for technical help.

\section{References}

1 Ayliffe, G A J, et al, Lancet, 1969, 2, 1117.

2 Bagshawe, K D, Blowers, R, and Lidwell, O M, British Medical fournal, 1978,2 , (in five parts) $609,684,744,808,879$

3 Tyrell, D A J, et al, British Medical fournal, 1977, 2, 373.

4 Ayliffe, G A J, et al, fournal of Hygiene, 1971, 69, 511.

5 Speers, R, et al, Lancet, 1969, 2, 233.

6 Ayliffe, G A J, et al, Fournal of Hygiene, 1977, 79, 299.

7 Ayliffe, G A J, Lilly, H A, and Lowbury, E J L, Lancet, 1979, 1, 538.

${ }^{8}$ Casewell, M, and Phillips, I, British Medical fournal, 1977, 2, 1315.

${ }^{9}$ Lidwell, O M, et al, Fournal of Applied Bacteriology, 1974, 37, 649.

${ }^{10}$ Hambraeus, A, fournal of Hygiene, 1973, 71, 799.

11 Ayliffe, G A J, Babb, J R, and Quorairshi, A H, Fournal of Clinical Pathology, 1978, 31, 923.

12 Taylor, L J, Nursing Times, 1978, Jan 12, p 54, Jan 19, p 108.

(Accepted 9 fuly 1979)

\title{
Effects of inflammatory disease on plasma oxprenolol concentrations
}

\author{
M J KENDALL, CHARMAINE P QUARTERMAN, HILARY BISHOP， R E SCHNEIDER
}

British Medical fournal, 1979, 2, 465-468

\section{Summary and conclusions}

When single oral doses of oxprenolol were given to three healthy subjects on three separate occasions under standardised conditions the plasma concentration-time curves for each subject were closely similar. In two of the subjects, however, a mild illness led to a dramatic, temporary increase in the peak plasma concentration and area under the plasma concentration-time curve (AUC). This effect of inflammatory disease was confirmed by comparing a group of patients with an erythrocyte sedimentation rate (ESR) of over $20 \mathrm{~mm}$ in the first hour with a group whose ESR was below this value. The mean peak plasma concentration and AUC were significantly higher in the group with a raised ESR. This may be related to altered concentrations of one of the acute-phase proteins.

Thus it is concluded that plasma oxprenolol concentra-

\footnotetext{
Department of Therapeutics and Clinical Pharmacology, Queen Elizabeth Hospital, Birmingham B15 2TH

$M$ J KENDALL, MD, MRCP, senior lecturer in therapeutics and clinical pharmacology, and honorary consultant physician CHARMAINE P OUARTERMAN, BSC, research technician HILARY BISHOP, research technician

R E SCHNEIDER, MD, FRCPED, senior honorary research fellow
}

tions are raised in inflammatory disease, but further work is needed to determine the mechanism of this increase.

\section{Introduction}

Drugs are usually given to young, healthy volunteers before being given to patients. Care must then be taken when extrapolating from data on blood concentrations obtained in this way to patients, who are often older, may be taking other drugs, and are ill. Patients with various inflammatory diseases attain much higher plasma propranolol concentrations than healthy controls. ${ }^{1}$ This prompted us to assess the effects of inflammatory disease on the plasma concentrations of other beta-blockers differing from propranolol in their protein-binding characteristics and route of elimination. Oxprenolol is less protein bound $\left(70^{\circ}\right.$ as opposed to $\left.93 \%{ }^{2}\right)$, and most is conjugated with glucuronic acid by the liver, unlike propranolol, which is degraded to several metabolites. ${ }^{3}$

We report here the results of two separate studies. The first determined the reproducibility of the plasma concentrationtime curves of oxprenolol in three subjects. In two of these the fortuitous development of an acute infection during the study allowed us to assess the effect of such an illness on the plasma oxprenolol concentrations. In the second study we compared the plasma oxprenolol concentrations in a group of patients with chronic inflammatory diseases associated with a raised erythrocyte sedimentation rate (ESR) with those in a group of subjects with normal ESR values. 


\section{Methods}

SUBJECTS

The first part of the study was carried out on three initially healthy women volunteers $(A, B$, and $C$ ) aged 19,20 , and 19 years and weighing $66,51 \cdot 5$, and $58.5 \mathrm{~kg}$ respectively. All were clinically well when first seen. They were not receiving any concomitant medication, and haematological and biochemical screening yielded normal results.

The second part of the study was carried out on two groups of nine subjects. One group, all with an ESR of over $20 \mathrm{~mm}$ in the first hour (range 25-100, mean 56), consisted of five men and four women aged 28-71 years (mean 51). Six of these had rheumatoid arthritis, and the remaining three had Crohn's disease, back pain, or hypertension. The controls, defined simply as being subjects with an ESR of less than $20 \mathrm{~mm}$ in the first hour, were six men and three women with an ESR of 1-19 $\mathrm{mm}$ in the first hour (mean 7) aged 22-56 years (mean 36). They consisted of three healthy volunteers and six people undergoing various investigations. None of these subjects was taking other drugs on the day of the study, and none had evidence of hepatic or renal dysfunction.

\section{TRIAL TECHNIQUES}

To determine the reproducibility of the plasma concentration-time curve under standardised conditions each of the three subjects attended at 9 am on three occasions at intervals of not less than one week, having fasted overnight. A cannula was inserted into a forearm vein and connected by a three-way tap to an intravenous giving set through which physiological saline was slowly perfused. One tablet of oxprenolol $80 \mathrm{mg}$ was given with $100 \mathrm{ml}$ water, and blood samples were taken before dosing and at intervals (see fig 1) up to six hours through the three-way tap while the subjects remained supine. The cannula was then removed and samples obtained by venepuncture at eight, 12, and 24 hours. Each sample was collected into a heparinised tube and centrifuged and the plasma stored at $-20^{\circ} \mathrm{C}$ until analysed. Drinks were given after two and five and a half hours, and lunch was provided three and a half hours after taking the tablet.
On the day of her third attendance volunteer $\mathrm{A}$ felt unwell and had a sore throat. Because the results then were higher than those obtained on the two previous visits she was asked if she would repeat the study while still feeling unwell. This she did, and her ESR on the second visit was $37 \mathrm{~mm}$ in the first hour. After fully recovering she returned for the fifth time to do her third reproducibility study. Volunteer $C$ developed an influenza-like illness during the day of the third study. The results of this day are therefore considered separately, and like her colleague she was subsequently recalled when she had fully recovered.

In the group study the dose of oxprenolol used was $40 \mathrm{mg}$, since preliminary trials had suggested that high plasma drug concentration could occur in the patients with inflammatory disease. The techniques used and the timing of samples were similar to those in the initial study.

Oxprenolol analysis-Plasma samples were assayed for oxprenolol by the gas chromatographic method described elsewhere. ${ }^{45}$ The method entails using solvent extraction of the oxprenolol and the internal standard metoprolol, and subsequent conversion to a trifluoracetyl derivative. Gas chromatography was carried out using a column packed with $3 \% \mathrm{OV}-1$ on Gas Chrom $\mathrm{Q}$ (100-120 mesh) and $5 \%$ methane in argon as the carrier gas having a flow rate of $60 \mathrm{ml} / \mathrm{min}$. The injection port, detector, and oven temperature settings were $250^{\circ} \mathrm{C}, 300^{\circ} \mathrm{C}$, and $180^{\circ} \mathrm{C}$ respectively.

Data analysis-Areas under the plasma concentration-time curve (AUCs) were calculated using the trapezoidal rule and apparent half-life values determined by linear regression of the log-linear postabsorptive phase. Because of the few data points in this region of the plasma profile only a single elimination phase could be calculated, even though it has been possible to describe the pharmacokinetics of oxprenolol as a three-compartment model with intermediate and terminal elimination phases. ${ }^{6}$

\section{Results}

Fig 1 shows the reproducibility of the plasma concentration-time curve when $80 \mathrm{mg}$ oxprenolol was taken while fasting under standardised conditions. The variation was small. Fig 2 shows the pronounced effect produced by a relatively mild infection in two of the subjects.
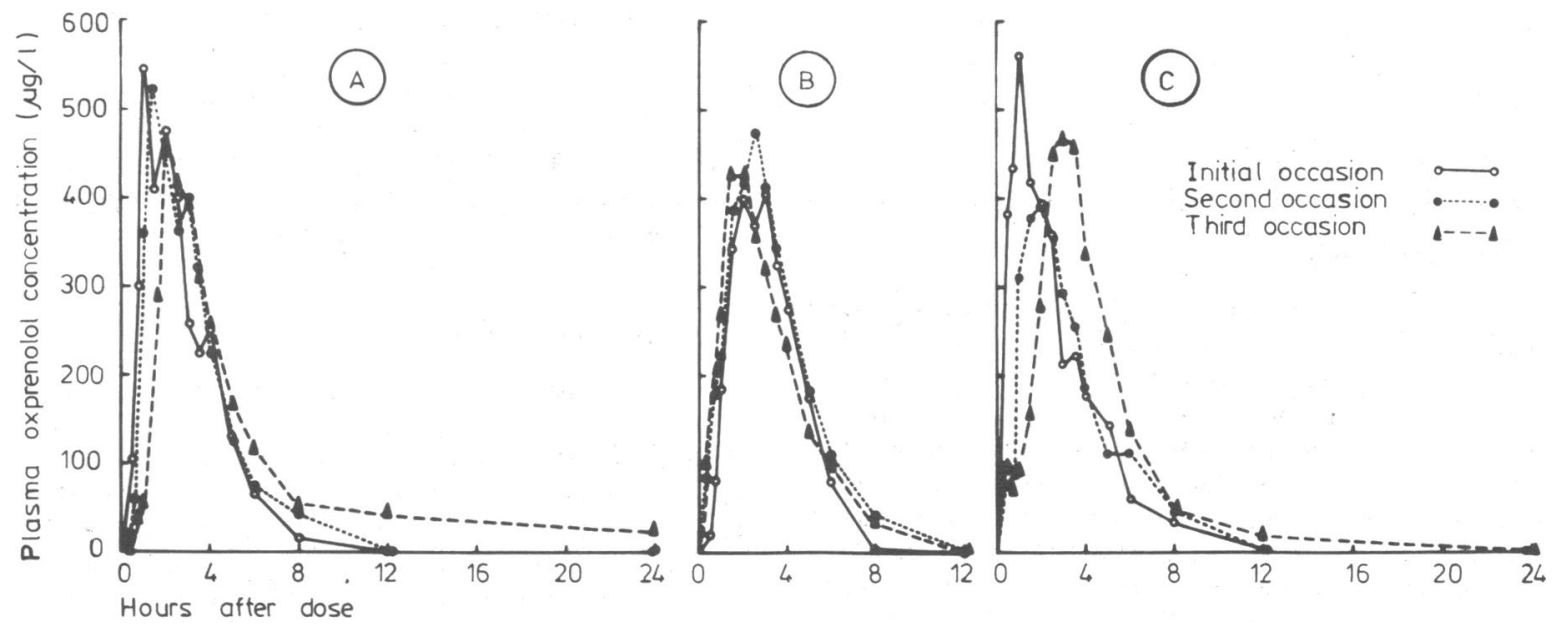

FIG 1-Plasma concentration-time curves obtained after oral administration of $80 \mathrm{mg}$ oxprenolol on three occasions to three separate subjects (volunteers $\mathrm{A}, \mathrm{B}$, and $\mathrm{C}$ ).

Pharmacokinetic indices for oxprenolol obtained while volunteers were well (visit numbers 1, 2, and 3) and ill (visit numbers 4 and 5 )

\begin{tabular}{|c|c|c|c|c|c|c|c|c|c|}
\hline \multirow{3}{*}{$\begin{array}{l}\text { Visit } \\
\text { No }\end{array}$} & \multicolumn{9}{|c|}{ Volunteers } \\
\hline & \multicolumn{3}{|c|}{ A } & \multicolumn{3}{|c|}{ B } & \multicolumn{3}{|c|}{ C } \\
\hline & $\underset{(\mu \mathrm{g} / 1)}{\operatorname{Cmax}}$ & $\underset{(\mu \mathrm{g} / \mathrm{l} \mathrm{h})}{\mathrm{AUC}}$ & $\underset{\text { (h) }}{\text { Half life }}$ & $\underset{(\mu \mathrm{g} / \mathrm{I})}{\mathrm{Cmax}}$ & $\underset{(\mu \mathrm{g} / \mathrm{l} h)}{\mathrm{AUC}}$ & $\underset{\text { (h) }}{\text { Half life }}$ & $\underset{(\mu \mathrm{g} / 1)}{\mathrm{Cmax}}$ & $\underset{(\mu \mathrm{g} / \mathrm{I} h)}{\mathrm{AUC}}$ & $\underset{\text { (h) }}{\text { Half life }}$ \\
\hline $\begin{array}{l}1 \\
2 \\
3 \\
4 \\
5\end{array}$ & $\begin{array}{l}544 \\
522 \\
459 \\
887 \\
888\end{array}$ & $\begin{array}{l}1671 \\
1725 \\
2098 \\
3336 \\
3220\end{array}$ & $\begin{array}{l}1.5 \\
1.2 \\
1.7 \\
1.4 \\
2.1\end{array}$ & $\begin{array}{l}426 \\
402 \\
477\end{array}$ & $\begin{array}{l}1684 \\
1537 \\
1868\end{array}$ & $\begin{array}{l}1.5 \\
1.3 \\
1.5\end{array}$ & $\begin{array}{l}561 \\
383 \\
469 \\
729\end{array}$ & $\begin{array}{l}1732 \\
1569 \\
1951 \\
2781\end{array}$ & $\begin{array}{l}1.7 \\
1.8 \\
1.2 \\
1.9\end{array}$ \\
\hline
\end{tabular}

Cmax = Peak plasma concentration.

AUC $=$ Area under plasma concentration-time curve $(24 \mathrm{~h})$. 

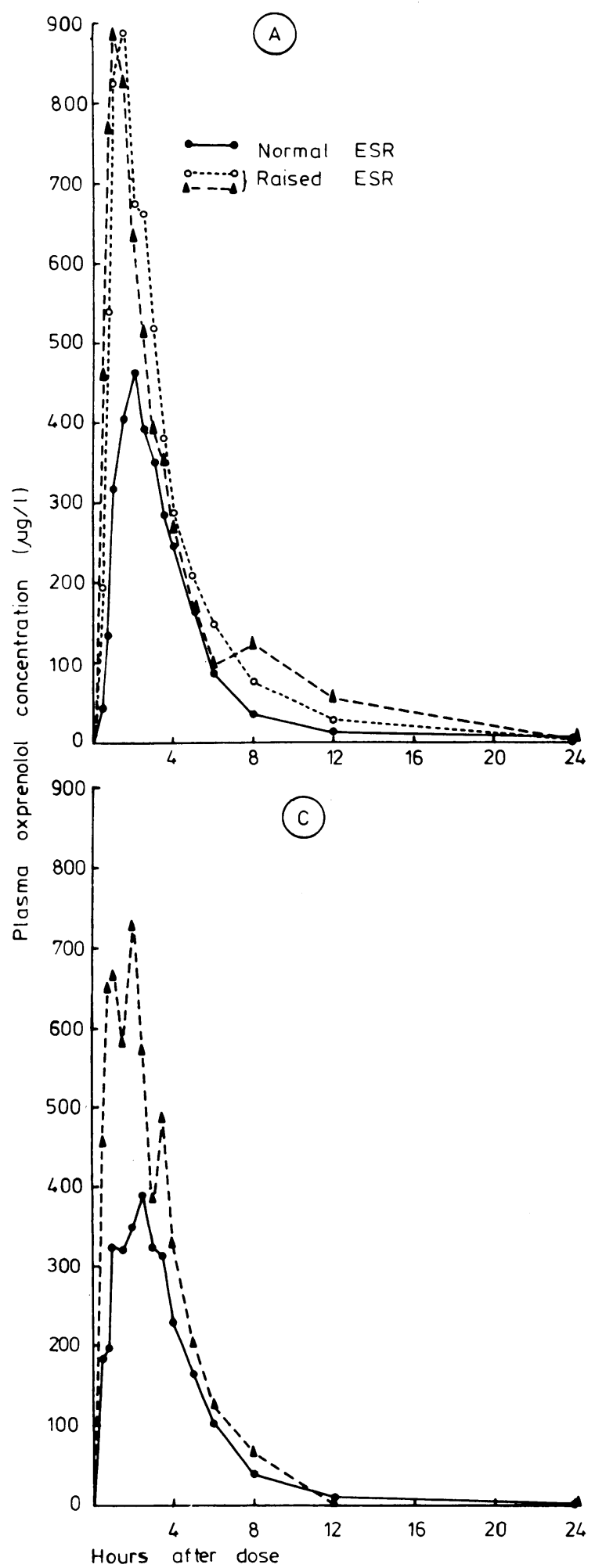

FIG 2-Effects of minor illnesses on plasma concentrations of oxprenolol in two subjects (volunteers $\mathrm{A}$ and $\mathrm{C}$ ) after an $80 \mathrm{mg}$ oral dose. The continuous line is the mean of the three results shown in fig 1 .

ESR = Erythrocyte sedimentation rate.

For clarity the normal results in this figure are presented as a single line, which is the mean of the three curves for that subject shown in fig 1 . In both instances a normal curve was obtained before the illness and again after they had fully recovered. The table shows the main pharmacokinetic indices derived from these studies.

Fig 3 shows the mean plasma oxprenolol concentration-time curves of the groups with the high and low ESRs. The mean ( \pm SE of mean) AUC of the group with ESRs $\because 20 \mathrm{~mm}$ in the first hour $(3173 \pm 429$ $\mu \mathrm{g} / \mathrm{l} \mathrm{h})$ was significantly greater $(\mathrm{P}<0.02)$ than that of the group with low ESRs $(1570 \pm 409 \mu \mathrm{g} / 1 \mathrm{~h})$.

The mean of the peak concentrations attained by members of the group with high ESRs $(951 \pm 155 \mu \mathrm{g} / \mathrm{l})$ was significantly higher $(\mathrm{P}<0.02)$ than that of the group with low ESRs $(481 \pm 69 \mu \mathrm{g} / \mathrm{l})$. The times to peak, however, were similar $(1.4 \mathrm{~h}$ and $1.2 \mathrm{~h})$. There was no obvious correlation between the heights of the ESRs and peak concentrations or AUCs.

\section{Discussion}

These results show that, whereas under controlled conditions the plasma concentration-time curve obtained in any subject with an oral dose of oxprenolol is fairly reproducible, inflammatory disease dramatically alters it. This has important implications. The clinician should be aware that some drugs such as oxprenolol and propranolol ${ }^{1}$ may reach higher concentrations in plasma when given to people who are suffering from any disorder that may cause a raised ESR. The effects and side effects after one or two doses may therefore be more pronounced, though what would happen during chronic administration remains to be determined. The clinical pharmacologist also needs to take care while carrying out pharmacokinetic studies to ensure that all the volunteers are quite well on the day.

The reason for these higher concentrations is not known, though a link with the increased concentrations of $\alpha_{1}$-acid glycoprotein found in inflammatory disorders ${ }^{7}$ is possible, since propranolol appears to bind to this protein. ${ }^{8} \mathrm{~A}$ recent observation $^{9}$ showing a strong positive correlation between $\alpha_{1}$-acid glycoprotein concentrations and the AUC suggests that the raised propranolol concentrations are produced, partly at least, because the concentrations of $\alpha_{1}$-acid glycoprotein, to which propranolol is bound, are raised.

Interestingly, the plasma curves of the young healthy volunteers shown in fig 1 are comparable to those obtained in other studies in which $80 \mathrm{mg}$ oxprenolol was given. ${ }^{6}{ }^{10}$ On the other hand, the peak value on the mean curve of the group chosen as controls (fig 3), who were given $40 \mathrm{mg}$ oxprenolol, was $388 \mu \mathrm{g} / \mathrm{l}$, which is higher than would have been expected from results in other studies using this dose. ${ }^{10} 11$ Although the reasons for this

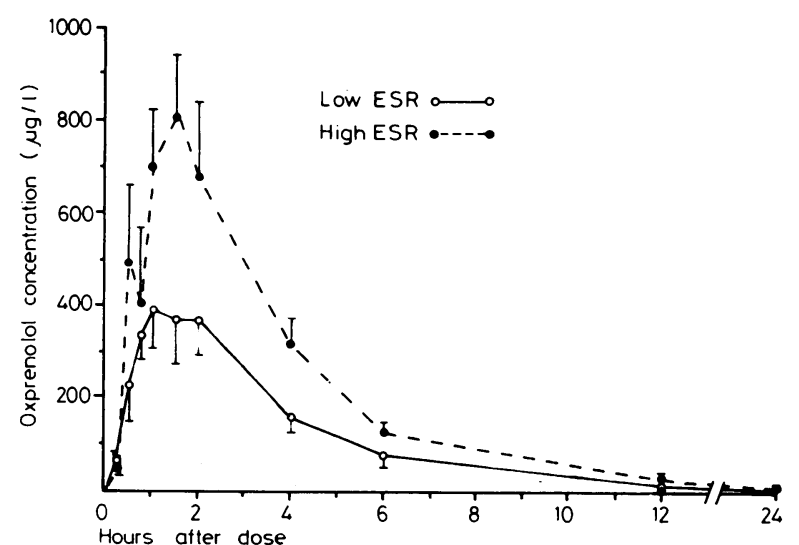

FIG 3-Mean plasma oxprenolol concentration-time curves after $40 \mathrm{mg}$ oral dose in group of subjects with raised and group with low erythrocyte sedimentation rate (ESR) (over and under $20 \mathrm{~mm}$ in first hour respectively). Vertical bars represent SE of mean.

are not known, the control group included people up to the age of 56 and some hospital patients and therefore differed from the typical group of young, healthy volunteers, which may be relevant.

Further work is necessary to determine the mechanism by which these raised plasma oxprenolol concentrations are produced in inflammatory disease.

We are grateful to Dr C F Hawkins, who allowed us to study 
patients under his care, and to Miss D Brown and Staff Nurse $R$ Gibson for technical help.

\section{References}

${ }^{1}$ Schneider, R E, et al, British Medical fournal, 1976, 2, 794.

2 Riess, W, Brechbuhler, S, and Theobald, W, Australian and New Zealand Fournal of Medicine, 1976, 6, suppl No 3, p 4.

${ }^{3}$ Riess, W, Huerzeler, H, and Raschdorf, F, Xenobiotica, 1974, 4, 365.

4 Jack, D B, and Riess, W, fournal of Chromatography, 1974, 88, 173.
${ }^{5}$ West, M, et al, British fournal of Clinical Pharmacology, 1976, 3, 439.

${ }^{6}$ Kendall, M J, et al, European Fournal of Drug Metabolism and Pharmacokinetics, 1976, 3, 155 .

7 Lancet, 1979, 1, 368.

${ }^{8}$ Piafsky, K M, et al, New England fournal of Medicine, 1978, 299, 1435.

${ }^{9}$ Schneider, R E, et al, Lancet, 1979, 1, 554.

"Mason, W D, and Winder, N, Clinical Pharmacology and Therapeutics, 1976, 20, 401.

${ }^{11}$ Brunner, L, Imhof, P, and Jack, D, European fournal of Clinical Pharmaco$\log y, 1975,8,3$

(Accepted 11 fuly 1979)

\title{
Meningococcal infections during infancy: confidential inquiries into $\mathbf{1 0}$ deaths
}

\author{
J R OAKLEY, A N STANTON
}

British Medical fournal, 1979, 2, 468-469

\section{Summary and conclusions}

The first 10 deaths from meningococcal infections in children aged under 2 years that were reported to a DHSS multicentre study were reviewed. Confidential inquiries were made of the parents, family doctors, health visitors, and hospital staff concerned with each case, and management was discussed with a paediatrician and pathologist. Diagnosis and treatment were often delayed because doctors did not realise the importance of the purpuric rash. One child died at home, and by the time they were admitted to hospital all the remaining nine were shocked and needed resuscitation. Prodromal symptoms, mainly changes in behaviour, preceded the rash in all cases.

These prodromal symptoms should arouse the suspicion of septicaemia and prompt a search for petechiae so that early effective treatment may be started.

\section{Introduction}

Meningococcal infections may kill within a few hours of the onset of symptoms, and the death rate is particularly high among children aged under 2 years. ${ }^{12}$ The difficulties of diagnosis have recently been emphasised, ${ }^{3}$ and a high degree of suspicion is necessary if the correct diagnosis is to be made in time for the illness to be treated successfully. We report here on confidential inquiries into the first 10 deaths from meningococcal infections reported to the DHSS multicentre study of postneonatal mortality.

University of Sheffield, Children's Hospital, Sheffield S10 2TH J R OAKLEY, DCH, MRCP, clinical co-ordinator, DHSS Multicentre Postneonatal Study

Department of Child Health, Royal Victoria Infirmary, Newcastleupon-Tyne NE1 4LP

A N STANTON, MRCP, senior research associate (now senior paediatric registrar, General Hospital, Northampton NN1 5BI)

\section{Patients and methods}

The DHSS multicentre study of all deaths of children aged 1 week to 2 years began collecting data in April 1976. During the first two years of the study, when 623 deaths were reported from seven centres in England and Scotland, 10 children died from Neisseria meningitidis infection, confirmed either by isolation of the organism or by the characteristic haemorrhagic rash and necropsy findings. Nine deaths occurred in hospital and one at home.

A standardised interview was obtained with each of the parents soon after the funeral; it included detailed questions about the symptoms of the terminal illness and the sequence of events leading to death. This information was compared with and supplemented by information gathered from hospital records of the admission and interviews with the family doctor, health visitor, and hospital attendants. When the documentation was completed each case was discussed locally with the help of a paediatrician and a pathologist. All those concerned with the medical care of the child were invited to this discussion and generally most came.

\section{Results}

Prodromal symptoms of altered behaviour preceded the appearance of a haemorrhagic rash in all cases by an average of 13 hours. The common symptoms reported were: irritability ( 9 cases), fever ( 8 ), missed feeds (7), an altered cry (6), drowsiness (6), and pallor (3). A diffuse, pale pink, macular prodromal rash affecting the face and trunk, and similar to that described by Easton et al, was noted in two cases. $^{4}$

The sequence of events is shown in the table. One child died at home and was only observed to have a rash when found dead in the

Progress of meningococcal illnesses in the 10 children

\begin{tabular}{cccccc}
\hline & & \multicolumn{4}{c}{ Intervals from onset of symptoms (h) } \\
\cline { 3 - 6 } $\begin{array}{c}\text { Case } \\
\text { No }\end{array}$ & $\begin{array}{c}\text { Age } \\
\text { (weeks) }\end{array}$ & $\begin{array}{c}\text { To appearance } \\
\text { of purpuric } \\
\text { rash }\end{array}$ & $\begin{array}{c}\text { To first } \\
\text { GP } \\
\text { contact }\end{array}$ & To admission & To death \\
\hline 1 & 35 & 9 & 14 & 15 & 16 \\
2 & 22 & 13 & 9 & 16 & 19 \\
3 & 42 & 12 & 7 & 9 & 16 \\
4 & 25 & 3 & 7 & 19 & 21 \\
5 & 31 & 13 & 14 & 25 & 38 \\
6 & 99 & 14 & 6 & 6 & 15 \\
7 & 39 & 13 & 15 & 16 & 21 \\
8 & 99 & 8 & 9 & 14 & 40 \\
9 & 11 & 14 & 5 & Home & 14 \\
10 & 11 & & & death & \\
\hline
\end{tabular}

*No GP contact. Fortuitous arrival of health visitor on a routine visit led to admission. 